\title{
RELATIVIZATION OF CONFLICTING INTERESTS BETWEEN THE DEVELOPMENT OF TRANSPORT AND TRANSPORT INFRASTRUCTURE AND NATURE PROTECTION
}

\author{
Milica Dobričić ${ }^{1} \&$ Milica Maksić ${ }^{2}$ \\ ${ }^{1}$ Ministry of Construction, Transport and Infrastructure, Serbia \\ Serbia, 11000 Belgrade, Kralja Milutina st.10a; e-mail: milica.dobricic@mgsi.gov.rs \\ ${ }^{2}$ Institute of Urban Planning City of Niš, Serbia \\ Serbia, 18000 Niš, 7. July st. 6, e-mail: mmaxic@gmail.com
}

\begin{abstract}
The paper points to the importance of spatial plans for relativization of conflicting interests (conflicts) between the development of transport and transport infrastructure, and nature protection. Through the analysis of case study - adopted Spatial Plan for the Spatial Purpose Area of the Special Nature Reserve Uvac, the way of relativization of conflicts between planned variants of the highway Belgrade-South Adriatic, section Pozega-Boljare E-763 and zones and regime of protection areas within the scope of this spatial plan, is shown. From the aspect of nature protection, the most favorable variant of the highway, and proposed by this spatial plan, is indicated.
\end{abstract}

Keywords: Highway Belgrade-South Adriatic, section Požega-Boljare E-763, Spatial Plan for the Spatial Purpose Area of the Special Nature Reserve Uvac, conflicts, Serbia.

\section{INTRODUCTION}

The identification of potentially conflicting interests (conflicts) between different uses of space and the establishment of the starting points and the principles for their relativization are part of the process of spatial planning, and in particular, the spatial plans of special purpose areas. Spatial plans of special purpose areas in Serbia are type of spatial plans adopted by the Government of the Republic of Serbia and elaborated for areas requiring a special regime of protection, organization, arrangement and use of space, including the infrastructural transport corridors, areas with natural or cultural values, etc [7]. Spatial plans must be mutually agreed, primarily with the roof planning document - the Spatial Plan of the Republic of Serbia [2].

The Law on the Spatial Plan of the Republic of Serbia from 2010 to 2020 [11] determined the conception of the development of transport and transport infrastructure in the Republic of Serbia and set as the one of the strategic priorities in this area the implementation of activities on the state road I (construction of the E-763 highway) part of the route 4 (SEETO): Belgrade - Čačak - Požega - Arilje - Ivanjica - Sjenica (Duga Poljana) - Boljare (border with Montenegro) (whole route $4(601 \mathrm{~km})$ : Romanian border/Vatin - Belgrade (MNE) - Bar (MNE) [8]).

According to the Strategy for the development of rail, road, water, air and intermodal transport in the Republic of Serbia, the project Belgrade-Požega-South Adriatic, which represents the link between Corridor $X$ and Corridor IV in Romania with the Adriatic Sea, should contribute to the improvement of international, regional and domestic transport [12]. 


\section{IRTTIR Y $Y$ M}

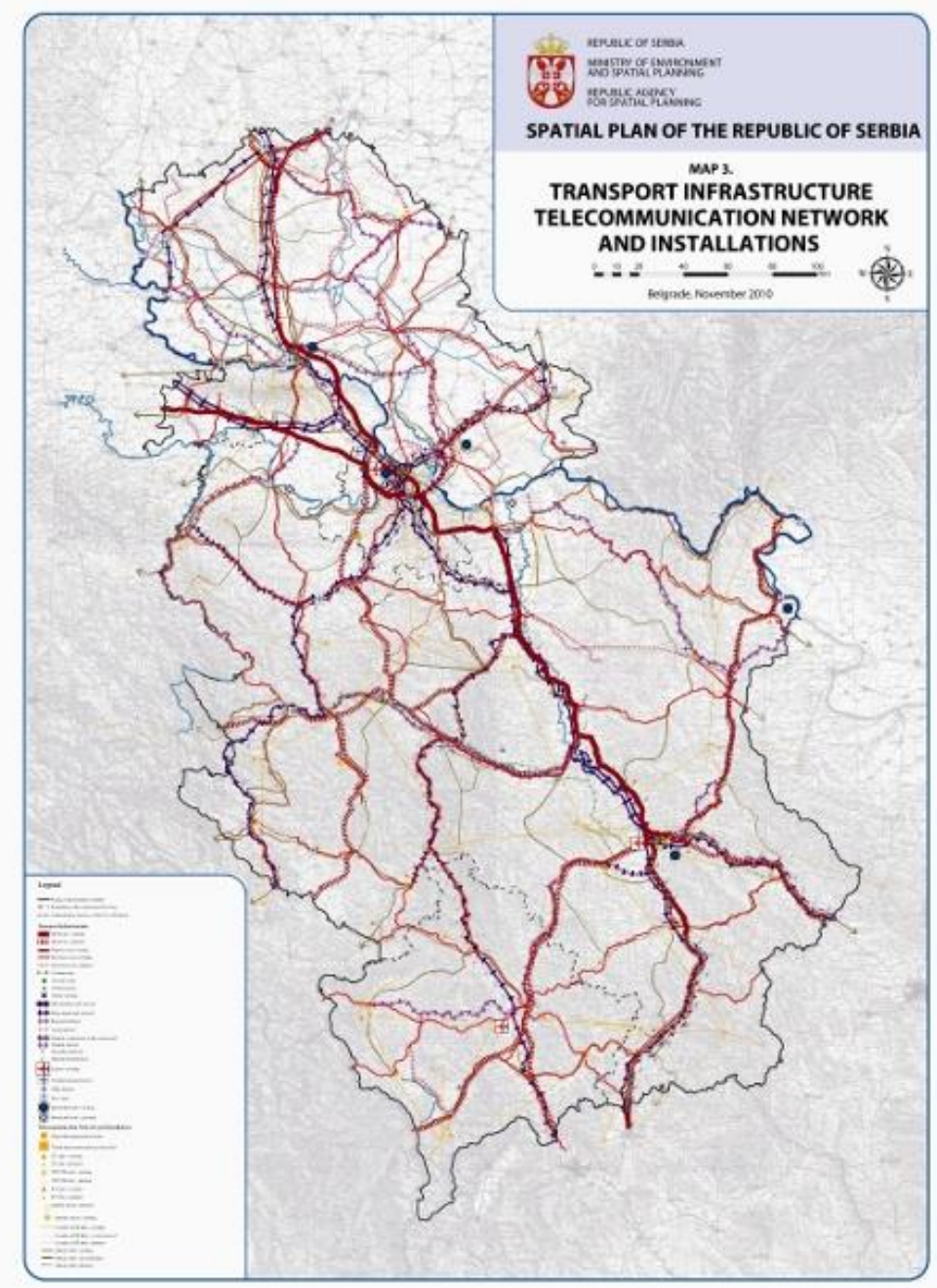

Figure 1. Transport infrastrucure, telecommunication network and installations - map 3, Spatial Plan of the Republic of Serbia, 2010 [13]

For the purpose of protecting, organizing, arranging and using the area of the Special Nature Reserve of Uvac, the Government of the Republic of Serbia has adopted the Spatial Plan of the special purpose area of the Special Nature Reserve of Uvac [10]. During the process of its development, potential conflicts were identified in the area. One of them was related to the conflict between the planned variants of the E-763 highway and the zones and the regimes of nature protection through which these variants pass - Uvac, Golija, Giljeva and Pešterska plateau. From the aspect of nature protection, this spatial plan gives the proposal of the most favorable variant of the E-763 highway. In this paper, through the analysis of example from practice, the importance and role of spatial plans in the relativization of conflicting interests in space is pointed out. 


\section{ARTTIE $Y$}

Ipplied Resseirlores in Technics, Technologies and Educration

Journal of the Faculty of Technics and Technologies, Trakia University https://sites.google.com/a/trakia-uni.bg/artte/

\section{MATERIALS AND METHODS}

\subsection{Study area}

The subjects of this study are the corridor of the planned highway Belgrade - South Adriatic, section Požega - Boljare E-763, part of Route 4 (SEETO) and areas of nature covered by the Spatial Plan of the special purpose area of the Special Nature Reserve of Uvac - Special Nature Reserve of Uvac, Nature Park Golija, the area of the mountain Giljeva and the Pešterska heights [10]. The planning area is located in the southwestern part of the Republic of Serbia and partly borders with Montenegro.

The planned E-763 highway corridor, for which the General project of E-763 highway from Požega to Boljare with three variants of the so-called Eastern Corridor - Central, East 1 and East 2, was made, is a section of the future Belgrade-South Adriatic highway. It should provide high quality transport connection between Serbia and Montenegro, through the Pešterska plateau and should enable the improvement of the transboundary linkage and economic cooperation between the two countries [10]. Požega-Boljare section aims to improve the development of the gravitational area, maximally preserve the environment in the planned highway corridor, enable optimum servicing with high capacity and quality transport, etc. [3].

The Special Nature Reserve of Uvac is an area protected by the Decree of the Government of the Republic of Serbia in 2006, as a natural good of exceptional importance of category I [6]. It is located on the parts of the territories of the municipalities of Nova Varoš and Sjenica, with a total area of $7543 \mathrm{ha}$, and a level II of protection regime is established within its area. The protection zone of the Special Nature Reserve is defined on the parts of the territories of municipalities Nova Varoš, Sjenica, Prijepolje and Ivanjica and it includes the area of the Uvac River Basin around the protected area, upstream of the profile of the dam of the Radoinja water storage. This area has numerous natural values and some of them are: Gyps fulvus habitat, which has the largest colony with 45 nesting pairs of Serbia and the Balkan peninsula in the Uvac area; attractive elements of the relief presented by a series of fused meanders of the river Uvac; etc.

Golija Nature Park is an area proclaimed by the decree of the Government of the Republic of Serbia in 2001 [5] as a natural good of exceptional importance of category I. This area includes the mountainous areas of Golija and Radočela and the source of Moravica and Studenica rivers, with a total area of $75183 \mathrm{ha}$ in parts of the territories of five municipalities (Ivanjica, Kraljevo, Raška, Novi Pazar and Sjenica). Within the scope of the Spatial Plan of the special purpose area of special nature reserve of Uvac, there is a part of Golija Nature Park, which covers 5890 ha on the parts of the territories of the municipalities of Sjenica and Ivanjica. In the area of the Nature Park, a three-stage protection regime has been established and in the scope of the Spatial Plan of the special purpose area of Special Nature Reserve of Uvac, there are parts of the zones with protection regimes of II and III degree. The beauty of the area, the cultural goods and the quality of natural resources are just some of the values of this protected area [9].

Mountain Giljeva is area planned for protection as a natural good. It includes a spacious plateau of the Giljeva mountains including Duga Dolina and Đalovića gorge. This area with numerous natural values is primarily the most prominent example of karst terrains of Serbia. It is located on parts of the territory of the municipality of Sjenica, with a surface area of about 10150 ha [10].

Pešterska plateau is an area planned for protection as a natural good. It encompasses the area on the southeast and south sides of the Pešterska field, of specific karstic morphology, climatic, landscape and other features. It is located on parts of the territories of the municipalities of Sjenica and Tutin, with a surrounding area of about 9100 ha [10].

IRTIIE Vol. 5, No. 4, 2017 ISSN 1314-8788 (print), ISSN 1314-8796 (online), doi: 10.15547/artte.2017.04.002 


\section{AR'TIE}

Ipplied Reseirl'ches in Technics, Technologies and Bduration Journal of the Faculty of Technics and Technologies, Trakia University https://sites.google.com/a/trakia-uni.bg/artte/

Table 1. Basic information about natural areas

\begin{tabular}{|l|c|c|c|}
\hline Natural area & year of designation & surface in ha & municipality \\
\hline $\begin{array}{l}\text { Special Nature } \\
\text { Rezerve Uvac }\end{array}$ & 2006 & 7543 & Nova Varos, Sjenica \\
\hline Nature Park Golija & 2001 & 75183 & $\begin{array}{c}\text { Ivanjica, Kraljevo*, Raška*, Novi } \\
\text { Pazar*, Sjenica }^{*}\end{array}$ \\
\hline $\begin{array}{l}\text { Mountain area } \\
\text { Giljeva }\end{array}$ & $\begin{array}{c}\text { proposed for } \\
\text { protection }\end{array}$ & 10150 & Sjenica \\
\hline $\begin{array}{l}\text { Area Pešterska } \\
\text { plateau }\end{array}$ & $\begin{array}{c}\text { proposed for } \\
\text { protection }\end{array}$ & 9100 & Sutin \\
\hline
\end{tabular}

* outside of the planning area

\subsection{Materials and Methods}

The research in this paper is based on the analysis of conflicting interests (conflicts) and their relativization, between the protected nature areas of the Special Nature Reserve of Uvac, the Golija Nature Park, the mountain of Giljeva and the Pešterska plateau and the three variants of the corridor of the planned highway Belgrade - South Adriatic, the section Požega Boljare E -763, as follows:

1. Variant Central - it is spread through the cadastral municipality (KO) Kušići (Ivanjica municipality), KO Ljepojevići (Nova Varoš municipality) and KO Kladnica, Ponorac, Ursule, Krstac, Čedovo, Uvac, Šušure, Trijebine, Dujke, Goševo, Boljare- the border of Montenegro (Sjenica municipality);

2. Variant Istok 1 - it is spread through KO Smiljevac, Vasiljevici, Erčege, Medovine (Ivanjica municipality) and KO Stup, Brnjica, Štavalj, Dragojloviće, Vrsjenice, Krće, Raždaginja, Dujke, Goševo, Boljare-Border of Montenegro (Sjenica municipality);

3. Variant Istok 2 - it is spread through KO Smiljevac, Vasiljevići, Erčege, Medovine (Ivanjica municipality) and KO Stup, Brnjica, Štavalj, Dragojloviće, Vrsjenice, Krće, Raždaginja, Dujke, Goševo, Boljare-border of Montenegro (Sjenica municipality) [10].

Table 2. Interaction of natural areas and highway E-763 variants

\begin{tabular}{|l|c|c|c|}
\hline Natural areas & variant central & variant east 1 & variant east 2 \\
\hline $\begin{array}{l}\text { Special Nature } \\
\text { Rezerve Uvac }\end{array}$ & $\sqrt{ }$ & \\
\hline Nature Park Golija & & $\sqrt{ }$ & $\sqrt{ }$ \\
\hline Mountain area Giljeva & $\sqrt{ }$ & $\sqrt{ }$ & $\sqrt{ }$ \\
\hline $\begin{array}{l}\text { Area Pešterska } \\
\text { plateau }\end{array}$ & $\sqrt{ }$ & & \\
\hline
\end{tabular}

\section{RESULTS AND DISCUSSION}

According to the Spatial Plan of the special purpose area of the Special Nature Reserve of Uvac, the variants of the planned corridor of the E-763 highway pass through the III degree of protection of the Special Nature Reserve Uvac, Nature park of Golija, Giljeva and Pešterska plateau (figure 2). It should be noted that for the areas of the nature of Giljeva and Pešterska plateau which are proposed for protection, this spatial plan of the special purpose area has established the III degree of protection until their proclamation, as well as for the protection zone of the Special Nature Reserve of Uvac [10].

The central variant of the highway corridor of the planned highway E-763 passes through the III degree of protection of the Special Nature Reserve of Uvac and the areas of the mountain 


\section{ARTIL \\ V \\ Ipplied Resseirlores in Technics, Technologies and Educration \\ Journal of the Faculty of Technics and Technologies, Trakia University https://sites.google.com/a/trakia-uni.bg/artte/}

Giljeva. The variant of East 1 passes through the III degree of protection of the Golija Nature Park and the Pešterska plateau. The variant East 2 passes through the protection regime of the III degree of the Golija Nature Park, the area of the mountain Giljeva and the Pešterska plateau area.

From the aspect of protection of natural assets, the Spatial plan of the special purpose area of the Special Nature Reserve of Uvac estimated variant of East 1 as a more favorable one. In addition to the above-mentioned, highway route was corrected in relation to Golija Nature Park, during the development phase of the General Project for the construction of this highway, based on the conditions of the Institute for Nature Protection of Serbia [4].

In addition, the Spatial Plan of the special purpose area of the Special Nature Reserve of Uvac has proposed variant East 1 as more favorable from the aspect of other criteria as well, such as protection of the water supply source. The area of the Special Nature Reserve coincides with the area of the West Morava-Rzava regional water supply source - subsystem Uvac, which is within the scope of the spatial plan. More precisely, by this spatial plan, the sanitary protection zones of the water supply sources of the Uvac subsystem, in the zone of protection of the Special Nature Reserve of Uvac, influenced the proposal of the most favorable variant of the E-763 motorway.

Some of the starting points and principles for the relativization of this conflict were the consistent application of regulations and standards of environmental protection, as well as the elaboration of a special Spatial plan for the special purpose area of the infrastructure corridor for the section of the highway Požega-Boljare (whose elaboration is under progress).

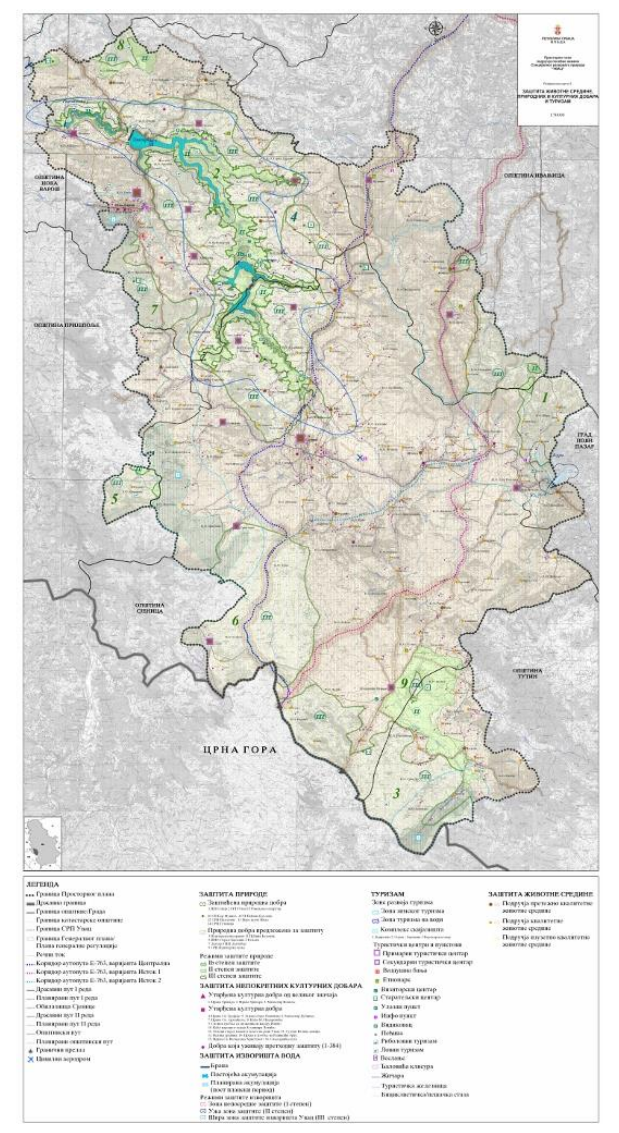

Figure 2. Variants of the E-763 highway on the Referal map 3. Environmental protection, natural and cultural goods and tourism, Spatial plan of the special purpose area of the

Special Nature Reserve of Uvac [10]

IRTIIE Vol. 5, No. 4, 2017 ISSN 1314-8788 (print), ISSN 1314-8796 (online), doi: 10.15547/artte.2017.04.002 


\section{CONCLUSION}

The construction of the E-763 Belgrade-South Adriatic highway in the Požega-Boljare section, part of Route 4 (SEETO), in line with the direction of the highway corridor determined by the Spatial Plan of the Republic of Serbia from 2010 to 2020, will be realized on the basis of variants developed with technical documentation at the level General project variants East 1, East 2 and Central.

Based on the conclusions of the Revision Commission on the adoption of the General Project of the E-763 highway from Požega to Boljare, all three variants of infrastructure corridor (East 1, East 2 and Central) will be evaluated on the basis of technical documentation at the level of feasibility study with the preliminary design, whereupon the final variant will be selected.

Until the final selection of the position of the corridor and the route of the highway, the Spatial Plan of the special purpose area of the Special Nature Reserve Uvac has reserved a space for the highway corridor, as follows: length of $52.54 \mathrm{~km}$ - variant East 1, about $56.58 \mathrm{~km}$ variant East 2 and around $61.68 \mathrm{~km}$ - variant Central, as well as the width of the corridor of about $700 \mathrm{~m}$, with the width of the highway profile on the mountainous terrain of about $25 \mathrm{~m}$ (two carriages separated by a divided island and the mutual banks), with the orientated position of the corridor on the reference map of the Spatial plan of the special purpose area of the Special Nature Reserve Uvac.

From the aspect of nature protection (and water supply sources), the Spatial Plan of the special purpose area of the Special Nature Reserve of Uvac has assessed that the most favorable variant is East 1. The final determination of the position of the highway corridor and the route, with the intersections of crossroads and denivelated crossings and accompanying contents, will be determined by the Spatial Plan of the Special Purpose Area of infrastructure corridor Belgrade - South Adriatic, the section Požega - Boljare, the border with Montenegro (E-763), based on technical documentation at the level of feasibility study with the conceptual design and environmental impact assessment. [10]

\section{REFERENCES}

[1] Dobričić, M. (2012). Planska zaštita i održivi razvoj međunarodno zaštićene prirodne i kulturne baštine u Srbiji - razvoj metodologije planiranja i programiranja razvoja. Beograd: Geografski fakultet, Univerzitet u Beogradu, neobjavljena doktorska disertacija. [Dobričić, M. (2012). The planned protection and sustainable development of internationally protected natural and cultural heritage sites in Serbia - developing the methodology for development planning and programming. Belgrade: Faculty of Geography, University of Belgrade, unpublished doctoral dissertation.]

[2] Law on Planning and Construction, Official Gazette of the Republic of Serbia, No.72/2009, 81/2009-correction, 64/2010-US, 24/2011, 121/2012, 42/2013-US, 50/2013US, 98/2013-US, 132/2014 and 145/2014.

[3] Pre-Feasibility Study for Highway E-763, Belgrade - South Adriatic, section III Požega border of Montenegro, Institute of Transportation CIP, Belgrade, 2007.

[4] Project of E-763 Motorway Construction, Section: Belgrade - Ostružnica - Požega Boljare/ Border of Montenegro. [Online]. Available: http://www.putevisrbije.rs/images/pdf/strategija/jjeng.pdf [2017-06-10].

[5] Regulation on protection of the Nature Park Golija, Official Gazette of the Republic of Serbia, No. 45/2001 and 47/2009.

[6] Regulation on protection of the Special Nature Reserve Uvac, Official Gazette of the Republic of Serbia, No. 25/2006 and 110/2006. 


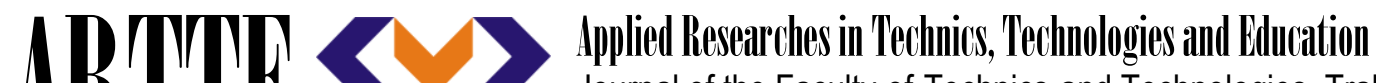 Journal of the Faculty of Technics and Technologies, Trakia University https://sites.google.com/a/trakia-uni.bg/artte/}

[7] Rule Book on Content, Manner and Procedure of Developing the Spatial and Urban Planning Documents, Official Gazette of the Republic of Serbia, No. 64/2015.

[8] South East Europe Transport Observatory (SEETO). [Online]. Available: http://www.seetoint.org/seeto-comprehensive-network/seeto-comprehensive-roadnetwork/routes/ [2017-06-18].

[9] Spatial Plan for the Spatial Purpose Area of the Nature Park Golija, Official Gazette of the Republic of Serbia, No. 16/2009.

[10] Spatial Plan for the Spatial Purpose Area of the Special Nature Reserve Uvac, Official Gazette of the Republic of Serbia, No. 83/2010.

[11] Spatial Plan of the Republic of Serbia 2010-2020, Official Gazette of the Republic of Serbia, No. 88/2010.

[12] Strategija razvoja železničkog, drumskog, vodnog, vazdušnog i intermodalnog transporta u Republici Srbiji od 2008. do 2015. godine. [Online]. Available: http://www.putevisrbije.rs/images/pdf/strategija/Strategijatransport_lat.pdf [2017-06-11].

[13] Transport infrastrucure, telecommunication network and installations - map 3, Spatial Plan of the Republic of Serbia, 2010. [Online]. Available: http://195.222.96.93//media/PPRSrbije\%20KARTE/ref.3engleski.jpg [2017-07-24]. 